\title{
Bogusław Kaczmarek*
}

\section{Zarządzanie międzykulturowe - wybrane aspekty}

Streszczenie: w opracowaniu prezentowane są następujące zagadnienia: istota, definicje i wymiary zarządzania międzykulturowego oraz modele międzykulturowej interakcji. Przedstawiona jest teza, że w zarządzaniu międzykulturowym nie powinno się stosować postaw skrajnych, czyli etnocentryzmu lub policentryzmu. Istotą zarządzania międzykulturowego jest znalezienie sposobu na asymilację różnorodności postaw i zachowań pracowników.

Słowa kluczowe: zarządzanie międzykulturowe, wielokulturowość, internacjonalizacja.

\section{Wprowadzenie}

Zarządzanie międzynarodowe, jako proces aplikacji koncepcji i technik zarządzania ponad granicami narodowymi czy państwowymi, jest praktycznie zarządzaniem w środowisku wielokulturowym. W środowisku tym funkcjonują lokalne kultury odznaczające się odmiennymi systemami wartości, które regulują stosunki między ludźmi i integrują życie lokalnej społeczności.

Zróżnicowanie kulturowe powoduje, że nie ma jednego, uniwersalnego stylu zarządzania, który można by skutecznie stosować w każdym kraju. W konkretnym przypadku należy spojrzeć na problemy organizacji i sposoby ich rozwiązywania z perspektywy innej kultury, niż własnej, ale nie należy też tracić z oczu punktów odniesienia do swojej.

Trzeba zatem zasymilować się z obcą kulturą na tyle, by efektywnie działać; trzeba pozostać w granicach wyznaczonych przez pewne określone przez tę kulturę parametry. Kultura kraju pochodzenia, jak również kraju działalności, oddziałuje na sposób w jaki menedżerowie podejmują decyzje oraz formułują i realizują cele instytucji. Wpływa ona na preferencje i postawy pracowników ,wyznaczając” adekwatny do nich system

* Katedra Zarządzania, Wydział Zarządzania, Uniwersytet Łódzki. 
motywacyjny. Współokreśla także styl pracy poprzez aspiracje i wizje świata zarówno pracowników, jak i kadry.

Jednocześnie czynniki kulturowe często traktowane są jako coś nieoczywistego i niesprecyzowanego. Efektem końcowym jest niedocenienie ich roli i wagi oraz niedostateczne uświadomienie potrzeby ich systematycznego zgłębiania i analizowania. Rzutuje to w efekcie końcowym na skuteczność działania i wyniki finansowe firmy.

Szczególnie mały jest wpływ - pod względem kultury - na wykonywanie zadań kulturowo „bardziej wrażliwych”, czyli takich jak: kadry i marketingu, w porównaniu np. do zarządzania sprawami technicznymi i skwantyfikowanymi jak: rachunkowość, finanse, produkcja, logistyka itp. Jednym z ważnych powodów takiego stanu rzeczy (wynika to z wielu badań) (zob. Todisko, 2009, s. 54) wydaje się być brak specjalistycznych komórek organizacyjnych w przedsiębiorstwach międzynarodowych zajmujących się zagadnieniami zarządzania międzykulturowego.

\section{Istota, definicje i wymiary zarządzania międzykulturowego}

W literaturze przedmiotu podkreśla się mocno konieczność wspomagania funkcji zarządzania przez zarządzanie międzykulturowe, którego głównym przedmiotem zainteresowania jest badanie związków między zarządzaniem a wynikami kulturowymi. Zarządzanie międzykulturowe opiera się na założeniu, że kultura wpływa na normy i wartości, postawy i zachowania uczestników organizacji.

A.K. Koźmiński (1999, s. 205) określa zarządzanie międzykulturowe mianem „operacji na kulturze”, polegającej na podejmowaniu działań w sferze społecznej organizacji oraz w świadomym dążeniu do zmiany jej struktury, aby mogła ona radzić sobie z wielokulturowością. M. Rozkwitalska (2007, s. 225) pisze, że „zarządzanie międzykulturowe koncentruje się na zagadnieniach organizacyjnych w układach międzynarodowych oraz interakcjach wielonarodowej społeczności pracowników". Według G. Hofstede (2000, s. 79) ,zarządzanie międzykulturowe koncentruje się na zachowaniach organizacyjnych $\mathrm{w}$ układach międzynarodowych, na interakcjach ludzi pochodzących z więcej niż jednej kultury, działających w ramach ról organizacyjnych".

Wielokulturowość wywiera bardzo silny wpływ na wiele ważnych aspektów funkcjonowania przedsiębiorstw międzynarodowych. Dotyczy to zwłaszcza (Penc, 2008, s. 1107): 
- transferu technologii i metod zarządzania produkcją;

- rozpowszechniania się innowacji organizacyjnych;

- poziomej integracji procesów wytwarzania realizowanych celów i produktów w ramach firmy;

- relacji pomiędzy centralą a zagranicznymi filiami (chodzi tutaj o stopień swobody filii);

- stosunków międzyludzkich;

- zarządzania zasobami ludzkimi firmy;

- sposobu prowadzenia negocjacji.

Pierwsze trzy wymiary, tj.: integracja pozioma, transfer technologii i metod zarządzania produkcją oraz rozpowszechnianie innowacji organizacyjnych w ramach firmy, przebiegają łatwiej, gdy współpracujące ze sobą jednostki (filie) położone są w krajach stosunkowo bliskich kulturowo, tzn. o podobnym systemie norm i wartości, języku i religii. Możliwe jest wtedy również osiąganie korzyści w skali produkcji, marketingu i sprzedaży dzięki produkcji identycznych, bądź podobnych wyrobów na podobne kulturowo rynki. Natomiast współpraca pomiędzy jednostkami położonymi w krajach odległych kulturowo pociąga za sobą dodatkowe koszty. Bliskość kulturowa (a także geograficzna) wpływa na przyznawanie jednostkom korporacyjnym większej autonomii. Wielokulturowość wpływa także na takie obszary działalności przedsiębiorstwa jak stosunki międzyludzkie i negocjacje. W skrajnym przypadku może ona być źródłem konfliktów bądź braku porozumienia układających się stron.

Wpływ czynnika kulturowego daje się mocno zauważyć w zarządzaniu zasobami ludzkimi. Specyfika kulturowa i instytucjonalna rynków międzynarodowych, na których firma prowadzi operacje, wymusza podjęcie działań dostosowawczych do poszczególnych elementów systemu zarządzania kadrami. W szczególności chodzi o metody doboru, awansowania i zwalniania pracowników, zasady i instrumenty oceny ich pracy, wynagradzanie i szkolenia, a także kształtowanie stosunków pracy i prowadzenia negocjacji z organizacjami pracowniczymi. Duże znaczenie ma przy tym pozostawienie filiom dostatecznej swobody w zakresie realizacji zadań. Działania te mają umożliwić zwiększenie stopnia adekwatności i użyteczności polityki kadrowej oraz efektywności wykorzystania pracowników, a tym samym podniesienia konkurencyjności całej korporacji.

Adam Góral - prezes dużej międzynarodowej firmy Asseco Poland - zwraca szczególną uwagę na dobór ludzi w międzynarodowym otoczeniu w jakim mają oni pracować. Pisze tak: „w pierwszym półroczu 2016 roku podpisaliśmy jako firma prawie trzy tysiące kontraktów. Mówienie, że jestem w stanie to kontrolować jest dużym błędem. Dziś tkwię w zależności od tysięcy ludzi, w dodatku wywodzących się z równych kul- 
tur. To nie są sami Polacy, z którymi mam jakieś «podskórne porozumienie». U nas w firmie są ludzie z Rosji, Danii, Hiszpanii, Turcji, Izraela, Anglii itp. Tutaj znów swoje robi intuicja. Moje szczęście polega na tym, że mam rękę do «dobrych ludzi»" (Forbes, 2016, s. 28).

\section{Modele międzynarodowej integracji}

W praktyce zarządzania międzykulturowego wyróżnić można trzy główne modele międzykulturowej interakcji. Według A.K. Koźmińskiego są to (Koźmiński, op. cit., s. 207):

- model kulturowej dominacji;

- model kulturowego współistnienia;

- model współpracy kulturowej (kulturowego współdziałania).

Dominacja kulturowa polega na narzuceniu całej organizacji lub partnerom rozmów czy negocjacji stylu zarządzania jednostki macierzystej. Inne kultury są ignorowane lub dyskryminowane. Objawia się to poprzez określone struktury organizacyjne, stosowane procedury i wzorce działania, język i styl komunikowania się, przestrzegane normy i wartości, a także poprzez obsadę stanowisk kierowniczych.

Wspótistnienie kulturowe polega na poszukiwaniu kompromisu pomiędzy kulturą kraju macierzystego firmy a lokalną. Współistnienie to przybiera przeważnie formę swoistej separacji charakteryzującej się tym, że dwie społeczności realizują wyraźnie określone odrębne zadania i minimalizują wzajemne kontakty.

Współpraca kulturowa opiera się na założeniu, że dwie kultury mogą aktywnie oddziaływać na siebie, czego efektem może być powstanie nowych cennych wartości. Różnorodność kulturową traktuje się zatem nie jako przeszkodę, ale jako cenny zasób, który można wykorzystać do rozwoju organizacji.

Należy zauważyć, że im dany model jest łatwiejszy i mniej kosztowny we wdrażaniu i praktycznym stosowaniu, tym więcej posiada wad i tym mniej korzyści pozwoli osiągnąć w związku z kontaktem różnych kultur.

Zarządzanie różnicami kulturowymi można także rozpatrywać ze względu na relacje między centralą a jej filiami zagranicznymi. Stosując kryterium suwerenności decyzyjnej (rozróżniające rozwiązania od podejmowania wszystkich decyzji na szczeblu centrali do podejmowania ich zarówno przez centralę, jak i filie) wyróżnić można cztery główne rodzaje takich powiązań. Ich cechy charakterystyczne zostały zestawione w tabeli 1. 
Tabela 1. Typy orientacji firmy matki na oddziały w przedsiębiorstwie transnarodowym

\begin{tabular}{|c|c|c|c|c|}
\hline \multirow{2}{*}{$\begin{array}{c}\text { Aspekty } \\
\text { przedsiębiorstwa }\end{array}$} & \multicolumn{4}{|c|}{ Typy relacji } \\
\hline & $\begin{array}{c}\text { Etnocen- } \\
\text { tryczne }\end{array}$ & Policentryczne & Regiocentryczne & Geocentryczne \\
\hline $\begin{array}{c}\text { Kompleksowość } \\
\text { organizacyjna }\end{array}$ & $\begin{array}{c}\text { Kompleksowe } \\
\text { w kraju macie- } \\
\text { rzystym, proste } \\
\text { w kraju } \\
\text { goszczącym }\end{array}$ & $\begin{array}{l}\text { Zróżnicowane } \\
\text { i niezależne }\end{array}$ & $\begin{array}{l}\text { Głęboko współ- } \\
\text { zależne } \\
\text { regionalnie }\end{array}$ & $\begin{array}{c}\text { Rosnący sto- } \\
\text { pień zależności } \\
\text { i współzależno- } \\
\text { ści w skali } \\
\text { globalnej }\end{array}$ \\
\hline $\begin{array}{l}\text { Wiedza, } \\
\text { decyzyjność }\end{array}$ & $\begin{array}{c}\text { Wysoka } \\
\text { w firmie matce }\end{array}$ & $\begin{array}{l}\text { Stosunkowo } \\
\text { niska w firmie } \\
\text { matce }\end{array}$ & $\begin{array}{l}\text { Wysoka w fi- } \\
\text { liach; wysoka } \\
\text { współpraca po- } \\
\text { między filiami }\end{array}$ & $\begin{array}{l}\text { Współpraca } \\
\text { firmy matki } \\
\text { i filii } \\
\text { na świecie }\end{array}$ \\
\hline Ocena i kontrola & $\begin{array}{l}\text { Kryteria firmy } \\
\text { matki stoso- } \\
\text { wane w ocenie } \\
\text { pracy i pra- } \\
\text { cowników } \\
\end{array}$ & $\begin{array}{c}\text { Lokalnie } \\
\text { wypracowane } \\
\text { kryteria }\end{array}$ & $\begin{array}{l}\text { Kryteria opraco- } \\
\text { wywane regio- } \\
\text { nalnie }\end{array}$ & $\begin{array}{l}\text { Kryteria uni- } \\
\text { wersalne } \\
\text { i lokalne }\end{array}$ \\
\hline $\begin{array}{l}\text { Nagrody, kary, } \\
\text { motywowanie }\end{array}$ & $\begin{array}{c}\text { Wysokie } \\
\text { w firmie } \\
\text { matce, niskie } \\
\text { w filiach }\end{array}$ & $\begin{array}{c}\text { Duże } \\
\text { zróżnicowanie }\end{array}$ & $\begin{array}{l}\text { Nagrody za osią- } \\
\text { gnięcie celów } \\
\text { regionalnych }\end{array}$ & $\begin{array}{l}\text { Nagrody mię- } \\
\text { dzynarodowe } \\
\text { i lokalne } \\
\text { za osiągnięcie } \\
\text { celów } \\
\text { regionalnych } \\
\text { i światowych } \\
\end{array}$ \\
\hline $\begin{array}{c}\text { Komunikowanie, } \\
\text { przepływ } \\
\text { informacji }\end{array}$ & $\begin{array}{l}\text { Dużo poleceń, } \\
\text { nakazów, pou- } \\
\text { czeń z firmy } \\
\text { matki dla filii }\end{array}$ & $\begin{array}{l}\text { Niewiele } \\
\text { informacji } \\
\text { pomiędzy } \\
\text { filiami }\end{array}$ & $\begin{array}{c}\text { Niewiele } \\
\text { informacji do } \\
\text { i z firmy matki; } \\
\text { intensywna ko- } \\
\text { munikacja po- } \\
\text { między filiami }\end{array}$ & $\begin{array}{c}\text { Komunikacja } \\
\text { w obie strony } \\
\text { i pomiędzy } \\
\text { filiami } \\
\text { na świecie }\end{array}$ \\
\hline $\begin{array}{l}\text { Identyfikacja } \\
\text { geograficzna }\end{array}$ & $\begin{array}{c}\text { Taka jak } \\
\text { narodowość } \\
\text { właściciela }\end{array}$ & $\begin{array}{c}\text { Taka jak } \\
\text { w kraju } \\
\text { firmy matki }\end{array}$ & $\begin{array}{l}\text { Taka jak firmy } \\
\text { regionalnej }\end{array}$ & $\begin{array}{c}\text { Prawdziwie } \\
\text { globalna, iden- } \\
\text { tyfikująca się } \\
\text { z krajem } \\
\text { narodowym }\end{array}$ \\
\hline $\begin{array}{l}\text { Ciąglość } \\
\text { (rekrutacja, } \\
\text { zatrudnienie, } \\
\text { rozwój) }\end{array}$ & $\begin{array}{l}\text { Przygotowanie } \\
\text { pracowników } \\
\text { firmy matki do } \\
\text { objęcia } \\
\text { kluczowych } \\
\text { stanowisk } \\
\text { na świecie }\end{array}$ & $\begin{array}{l}\text { Pracownicy } \\
\text { z kraju gosz- } \\
\text { czącego przy- } \\
\text { gotowani do } \\
\text { objęcia stano- } \\
\text { wisk we wła- } \\
\text { snym kraju }\end{array}$ & $\begin{array}{l}\text { Pracownicy } \\
\text { regionalni } \\
\text { przygotowani do } \\
\text { objęcia kluczo- } \\
\text { wych stanowisk } \\
\text { w regionie }\end{array}$ & $\begin{array}{l}\text { Najlepsi pra- } \\
\text { cownicy przy- } \\
\text { gotowani do } \\
\text { objęcia kluczo- } \\
\text { wych stano- } \\
\text { wisk na świecie }\end{array}$ \\
\hline
\end{tabular}

Źródło: A. Murdoch (1999, s. 89-99). 
Wyróżnione w tabeli podstawowe aspekty przedsiębiorstwa ukazują obszary, w jakich najłatwiej zaobserwować można charakter powiazań pomiędzy firmą matką a jej oddziałem (handlowym bądź produkcyjnym), w szczególności, jeśli chodzi o pozostawienie mu swobody decyzyjnej. W zależności od skali delegowania decyzji na poziom lokalny, a także sposobu traktowania przez przedsiębiorstwo transnarodowe swoich filii i związków (lub ich braku), pomiędzy nimi, wyróżniono cztery typy relacji, tj. etnocentryczna, policentryczną, regionocentryczną i geocentryczną. Orientacje te określają równocześnie różne podejścia firmy do zagadnienia kulturowości (Daniels, Radebaugh, 2000, s. 127).

Zdaniem J.D. Danielsa i L.M. Radebaugha w sytuacjach międzykulturowych wystrzegać się należy postaw skrajnych, tj. egocentryzmu i policentryzmu, które nie zapewniają sukcesu $\mathrm{w}$ działaniach firmy matki. W przypadku egocentryzmu zagrożenie polega na ignorowaniu różnic i faworyzowaniu własnej kultury narodowej, w wyniku czego mogą powstawać liczne nieporozumienia i konflikty - szczególnie na linii menedżer-podwładny. Policentrym - wysuwając na plan pierwszy różnice kulturowe - może doprowadzić do utraty własnej tożsamości przez organizację oraz niemożności realizowania przez nią własnej spójnej strategii. W takiej sytuacji jednostki działające w poszczególnych krajach będą działać samodzielnie, naśladując zwyczaje otoczenia.

Konieczne jest zatem znalezienie złotego środka pomiędzy skrajnościami oraz podejmowanie działań w kierunku zrozumienia innych kultur. Zróżnicowanie kulturowe zwiększa uwrażliwienie na potrzeby różnych rynków, podnosi innowacyjność, kreatywność i zdolność organizacji do rozwiązywania problemów. Stanowić może tym samym źródło przewagi konkurencyjnej przedsiębiorstwa działającego na rynkach międzynarodowych.

Działanie w otoczeniu wielokulturowym (w różnych krajach) i wynikające z niego różnice w zarządzaniu wymagają integracji i koordynacji jednostek wchodzących w skład korporacji, aby nie dopuścić do atomizacji (oderwania się od pozostałych jednostek) i załamania się systemowego podejścia do łańcucha wartości (Gesteland, 2008, s. 239).

Integrację należy rozumieć jako tworzenie sieci powiązań, współpracy i współzależności pomiędzy poszczególnymi jednostkami korporacyjnymi, czego wynikiem są rosnące przepływy produktów, czynników i informacji w całej organizacji. Proces integrowania operacji, akcji i programów zarówno w ramach konkretnych funkcji, jak i pomiędzy funkcjami, rozwijany jest dzięki formalnym i nieformalnym sposobom tworzenia powiązań. Do pierwszej kategorii zaliczyć można: kontakty kierownictwa jednostek, specjalne stanowiska ds. kontaktów wewnątrzkorporacyjnych, 
międzyfunkcyjne zespoły, macierzowe struktury organizacyjne. Nieformalne więzi powstają natomiast poprzez tworzenie się powiazań dobrze znanych sobie osób oraz przez przestrzeganie wspólnych norm i wartości, czyli dzięki kulturze danej organizacji.

Integracja zróżnicowanych funkcjonalnie i rozproszonych geograficznie jednostek filii, przedsięwzięć, kooperujących zakładów warunkuje koordynację ich pracy w ramach systemu kooperacyjnego. Koordynacja dotyczy porządkowania i harmonizowania działań realizowanych zarówno wewnątrz firmy, jak i na zewnątrz, tzn. we współpracy z klientami, dostawcami i innymi kooperantami. Koordynacja polega zatem na takim doborze sieci powiązań i uzgodnień pomiędzy poszczególnymi jednostkami organizacyjnymi oraz między nimi a partnerami zewnętrznymi przedsiębiorstwa, w celu maksymalizowania przewagi konkurencyjnej firmy na konkretnych rynkach.

Przykładem takiej przewagi może być zdolność przedsiębiorstwa transnarodowego do szybkiego tworzenia nowych produktów idealnie dostosowanych do międzynarodowych rynków (czyli oczekiwań, gustów i upodobań klientów z różnych części świata). Umiejętność ta wynika $\mathrm{z}$ odpowiedniej koordynacji działu badań i rozwoju z działem marketingu. D.P. Cushman i S.S. King (2004, s. 76) formułują następujące warunki skutecznej kooperacji i koordynacji działu badań i rozwoju, marketingu oraz produkcji i logistyki:

- produkcja musi być oparta na zasadach maksymalizacji korzyści skali i zasięgu, minimalizacji czasu reakcji oraz na technologiach zapewniających elastyczność systemu;

- mechanizmy koordynacyjne muszą przecinać nie tylko granice jednostek organizacyjnych i pionów funkcjonalnych, ale także państw systemów politycznych, obszarów kulturowych i językowych itp.;

- mechanizmy koordynacji muszą być zarówno formalno-organizacyjne (oparte na skomputeryzowanych systemach informacyjnych), jak i całkowicie nieformalne (społeczno-kulturowe);

- konieczne jest stałe monitorowanie i ciągłe monitorowanie mechanizmów koordynacyjnych.

Uogólniając powyższe warunki można powiedzieć, że koordynowanie działań przedsiębiorstwa międzynarodowego polega w szczególności na:

- synchronizowaniu ogniw łańcucha wartości;

- zmniejszaniu kosztów transakcyjnych;

- krążeniu informacji pomiędzy poszczególnymi filiami oraz między nimi a organizacją macierzystą; 
- umiejętnym zarządzaniu współzależnościami, do czego niezbędne są: sprawny obieg informacji, sprawozdawczość, budżetowanie i system kontroli.

Tym samym, konieczne jest dokonanie określonych wyborów dotyczących geograficznego rozlokowania zasobów organizacji, podzielenia zadań związanych z realizacją operacji składających się na poszczególne ogniwa łańcucha, dobrania odpowiednich rozwiązań strukturalnych, określenia funkcji i ustalenia procedur. Ma to ułatwić rozwiazywanie konfliktów pomiędzy różnymi ogniwami łańcucha wartości i różnymi częściami (elementami składowymi) przedsiębiorstwa.

Generalnie uważa się, że skuteczna koordynacja działań realizowanych $\mathrm{w}$ różnych miejscach globu, różnych pionach funkcjonalnych przedsiębiorstwa, na zróżnicowanych rynkach i w różnych grupach projektowych, jest podstawą sukcesu przedsiębiorstwa. Determinuje ona zdolność firmy do konkurowania oraz akumulowania środków finansowych koniecznych do sprostania naciskom konkurentów w różnych krajach i obszarach geograficznych świata.

Koordynacja działań umożliwia ponadto zdobycie różnorodnych doświadczeń na bardzo odmiennych rynkach oraz dostęp do większej ilości informacji dotyczących produktów, technik marketingowych, czy polityki handlowej konkurentów. Pozwala wreszcie na rozproszenie bądź zmniejszenie ryzyka finansowego i prawno-ustrojowego obowiązującego w różnych krajach, tworzenie własnych źródeł zaopatrzenia i właściwe reagowanie na wahania koniunkturalne.

\section{Podsumowanie}

W zarządzaniu międzykulturowym zakłada się, że kultura będąca pochodną narodowości wywiera wpływ na role pełnione przez poszczególnych członków organizacji (np. przedsiębiorstwa międzykulturowego, globalnego, transnarodowego itp.). Zarządzanie międzykulturowe jest efektem tego, że współczesne przedsiębiorstwa działające na rykach zagranicznych posiadają pracowników i kontrahentów z różnych krajów i różnych kultur. Prezentują oni różne systemy wartości, normy zachowań i obyczajów. Powoduje to, że w takiej sytuacji ludzie (pracownicy) inaczej postrzegają rzeczywistość, inaczej myślą, czują i działają.

Istotą zarządzania międzykulturowego jest zatem znalezienie sposobu na asymilację różnorodności, która jest z kolei podstawowym warunkiem funkcjonowania i prowadzenia działalności w międzynarodowym otoczeniu. 


\title{
BIBLIOGRAFIA
}

Cushman D.P., King S.S. (2004), High Speed Management. A Revolution in Organizational Communications, NY Press.

Daniels J.D., Radebaugh L.M. (2000), Różnice kulturowe a zachowania w biznesie, PWN, Warszawa.

Forbes (2016), X.

Gesteland R.R. (2008), Różnice kulturowe a zachowania w biznesie, PWN, Warszawa.

Hofstede G. (2000), Kultury i organizacje, PWE, Warszawa.

Koźmiński A.K. (1999), Zarządzanie międzykulturowe, PWE, Warszawa.

Murdoch A. (1999), Wspótpraca z cudzoziemcami w firmie, Poltex, Warszawa.

Penc J. (2008), Encyklopedia zarządzania, WSSM, Łódź.

Rozkwitalska M. (2007), Zarządzanie międzynarodowe, Difin, Warszawa.

Todisko O. (2009), Od jednokulturowości do wielokulturowości, „Społeczeństwo”, nr 3.

\section{INTERCULTURAL MANAGEMENT - SELECTED ASPECTS}

\begin{abstract}
The study presents the following issues: the essence, definitions and dimensions of intercultural management and models of intercultural interaction. The study is presented the thesis that in intercultural management should not be used extreme attitudes or ethnocentrism or polycentrism. The essence of intercultural management is finding a way to assimilate the diversity of attitudes and behaviors of employees.
\end{abstract}

Keywords: intercultural management, multiculturalism, internationalization. 